\title{
NA 70 JAAR: 'N KORT OORSIG VAN DIE EERSTE WERELDOORLOG (1914-1919), MET BESONDERE VERWYSING NA DIE WESTELIKE FRONT EN SUID-AFRIKA SE DEELNAME
}

Kol. dr. Jan Ploeger*

In the early part of the 20th century there was a delicate balance of power prevailing among European nations. There were also several treaties between groups of nations whereby an attack on any one nation would involve several groups. The spark to this powder keg situation occurred when Arch-Duke Ferdinand was assassinated on 28 June 1914. The Austro-Hungarians declared war on Serbia which in turn brought in Russia, Germany, France and Great Britain. Britain's entry brought in the Commonwealth which included South Africa. This condensed history sketches the course of "The Great War" as it became known and highlights the role of the South African Forces.

\section{RECRUITS ARE REQUIRED}

FOR THE

\section{FIRST SOUTH AFRICAN INFANTRY BRIGADE.}

SFRVICF \& FOR DIRITION OF WAR existing tertwenn fireat kritain and Germany and six monthe aftor the tarmination of that War. provided services are so bong required.

Men mast be phrsically fit for servise in the tielil.

Yimintum bejpl

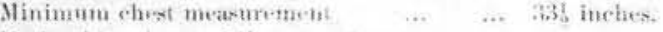

Pay a Tnion ratex and separation Altewance at Imperial rates will be paid to peoved dependesis when not reatiling with the soldier,

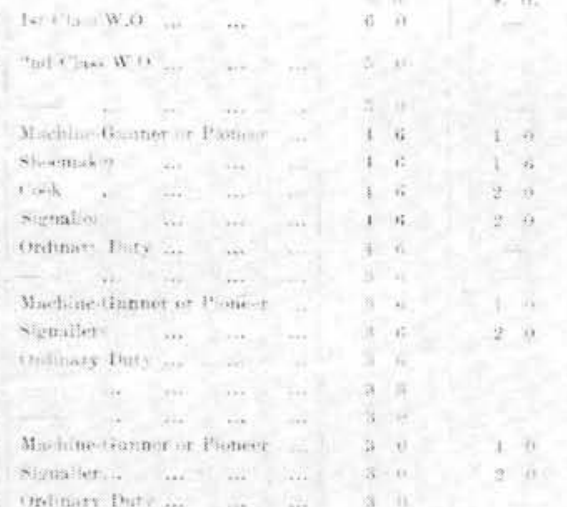


Die vernaamste oorlogsgebeurtenisse (1914-1919):

$1914-28.6 .1914$

$-28.7 .1914$

$-1.8 .1914$

$-2.8 .1914$

$-3.8 .1914$

$-4.8 .1914$

$-6.8 .1914$

$-23.8 .1914$

$-31.8 .1914$

- 3-11 Sept.

- 6-15 Sept.

- 11-11 Sept.

- Nov.-Des.
Die Oostenrykse troonopvolger Frans Ferdinand (1863-1914) en sy gade in Serajewo vermoor.

Oostenryks-Hongaarse ultimatum aan Serwië.

Oorlogverklaring deur Oostenryk-Hongarye aan Serwië.

Duitsland verklaar oorlog aan Rusland.

Die Duitse inval in België en Luxemburg.

Duitse oorlogverklaring aan Frankryk.

Engeland verklaar oorlog aan die Duitse ryk.

Oostenryk-Hongarye verklaar oorlog aan Rusland.

Japan tree aan die kant van Engeland en sy bondgenote tot die Eerste Wêreldoorlog toe.

Slag by Tannenberg (Duitsland, Rusland, Oos-Pruise).

Slag aan die Marne (Frankryk)

Turkye tree aan die kant van die Sentrale magte (Duitsland, Oostenryk-Hongarye) tot die stryd toe.

Slag van leper (België). Mislukte Duitse deurbraak-poging by Langemark (België).

- Des.1914-April 1915 Slag in die Karpate.

1915 - Slag by Soissons (Frankryk). Die Turke ruk op na die Suezkanaal. Slag in Champagne (Frankryk). Die Duitse duikbootoorlog begin. Die "Lusitania" gesink. Die stryd in die Dardanelle begin na die landing by Gallipoli. Italië tree aan die kant van Engeland en sy bondgenote (die Geallieerdes) tot die oorlog toe. Toetrede van Bulgarye tot die oorlog (aan die kant van die Sentrale magte). 9 Julie 1915, Oorgawe by Khorab (D. S.W.A.). Serwië deur die Sentrale magte verower.

1916 - Veldslae aan die Isonso (Italië). Die onbesliste stryd om Verdun (Frankryk). Seeslag in die Skagerrak (Noordsee). Russiese offensief onder leiding van Brussilow onder opperbevelhebberskap van tsaar Nikolaas II (1868-1918). Someroffensief van die Geallieerdes aan die westelike front (Somme, Frankryk). Julie 1916, Die slag van Delvillebos. Roemenië tree, aan die kant van die Geallieerdes, tot die stryd toe. Generaal-veldmaarskalk Von Hindenburg (1847-1934) word hoof van die generale staf van die Duitse veldleër, genl. Erich Ludendorff (1865-1937) aangestel as kwartiermeester-generaal. Offensief in Champagne. Engeland voer die diensplig in. Die Duitse leër verower Bukarest (Roemenië).

1917 - 16 Januarie 1917: Genl. J.C. Smuts dra die bevel in D.O.A. aan genl.-maj. A.R. Hoskins oor en vertrek na Europa. Duitsland begin met die onbeperkte duikbootoorlog. Tsaar Nikolaas II van Rusland tree af. Die Verenigde State verklaar oorlog aan Rusland. ' $n$ Groot slag woed 'n drietal maande in Vlaandere. 'n Tenkslag by Cambrai (Kameryk, Frankryk). Die Oktoberrevolusie breek uit in Sint Petersburg (Leningrad, Rusland).

1918 - Die veertienpuntprogram van president T.W. Wilson (1856-1924), in verband met ' $n$ moontlike vrede, word bekend gestel. Die vrede van Biest-Litowsk (Duitsland, OostenrykHongarye, Rusland) kom tot stand. Die Geallieerde strydkragte aan die westelike front kom onder ' $n$ eenhoofdige bevelhebberskap van maarskalk Ferdinand Foch (1851-1929). Die begin van die Geallieerde teenoffensief aan die westelike front. Die Duitse wapenstilstandsaanbod aan president Wilson. Die Russiese vorstelike gesin word vermoor. Hongarye word 'n republiek. Muitery op die Duitse oorlogsvloot in Kiel. Pole word 'n republiek. Die Duitse wapenstilstandsooreenkoms met die Geallieerdes in Compiègne (Frankryk) gesluit. Revolusie in Berlyn, gevolg deur die aftrede van keiser Wilhelm II (1859-1941). 'n Nuwe Duitse regering gevorm.

1919 - Ondertekening van die verdrag van Versailles en ander verdrae. 


\section{"Lord Kitchener had from the beginning prophesied a four years' war. Hardly any one supported him in that belief. At army headquarters in France it was reckoned that Germany could not hold out longer than two years. The general view persisted it would 'all be over by Christmas'." John Canning: Living History: 1914. London, 1967).}

Die begin van die twintigste eeu het, op die gebied van vreedsame samewerking onder die vooraanstaande volke van die wêreld, belowend gelyk. Die pasifisme het gegroei en die begeerte na internasionale samewerking het tot uiting gekom in die vredeskonferensies van Den Haag (1899, 1907), waar pogings aangewend is om die totstandkoming van 'n groter en 'n beter Europa te bevorder. Die groot struikelblok was ewewel die internasionale mededinging tussen die groot magte. Dit het tot imperialisme en daaruit voortvloeiende oorloë soos die Tweede Anglo-Boereoorlog (1899-1902) en die TurksItaliaanse oorlog (1911-1912) gelei. Dan was daar die neiging tot groep- of verbondsvorming wat tot mededingende militêre gereedheid en oorheersing van kleiner state gelei het. Voorbeelde van verbondsvorming was die Driekeiserverbond (1872) tussen Duitsland, Oostenryk en Rusland; die Duits-Oostenrykse defensiewe verbond teen Rusland (1879), die Drievoudige verbond van 1882 tussen Duitsland, Oostenryk en Italië, die Frans-Russiese verbond (1893), die Brits-Japanse verbond (1902), die Frans-Italiaanse verbond (1902), die Engels-Franse verbond of entente (1902) en die Engels-Russiese verbor,d (1907).

Uit hierdie neiging het internasionale spannings opgevlam, wat aanleiding tot die Balkankrisis van 1908, die Turks-Italiaanse oorlog van 1911 , die krisis in Marokko (1913) en die toenemende spanning tussen Serwië en die Oostenryks-Hongaarse staat laat opvlam het. Ook het die bewapeningswedloop toegeneem. Duitsland het in 1913 oor 'n staande leërmag van 870000 beskik. Frankryk het die militêre diensplig tot drie jaar verleng, terwyl Rusland sy militêre slaankrag uitgebrei het.

Op 28.6.1914 het die kruitvat ontplof deurdat die Oostenrykse troonopvolger, aartshertog Frans Ferdinand (1863-1914) en sy gade in Serajewo deur ' $n$ Serwiër vermoor is. Die aartshertog was 'n neef van keiser-koning Frans Josef van Oostenryk-Hongarye (1848-1916) en dié voorval het tot ' $n$ reeks besluite en verbonde van uiteenlopende inhoud en rigting gelei waardeur die optrede van verskillende lande ander lande beïnvloed het. Dit het die bestaande wankelende ewewig in die Europese politiek versteur.
Frankryk en Rusland, Duitsland en OostenrykHongarye het, in vyandig gesinde kampe gestaan en op 28.7.1914 het Oostenryk-Hongarye oorlog aan Serwië verklaar. Ander lande het begin mobiliseer of hulle slaggereed begin hou.

Op 31.7.1914 het Duitsland 'n ultimatum aan Rusland gestuur wat onbeantwoord gebly het. Duitsland het oorlog aan Rusland verklaar en Frankryk het, kragtens ' $n$ verbond, by Rusland gestaan. Brittanje het Frankryk ondersteun.

Op 2.8.1914 het Duitsland tot die aanval oorgegaan en die neutrale Luxemburg beset. Twee dae later was die onsydige België die slagoffer van 'n grootskaalse Duitse militêre aanslag. Engeland het die neutraliteit van België in die verlede gewaarborg en het twee dae later oorlog aan Duitsland verklaar. In dié verband het G.M. Trevelyan in sy History of England (London, 1941, p. 716) o.m. verklaar:

"Belgium was not the only reason why we were able to strike as a united people, in time, but only just in time, to prevent the fall of Paris and the Channel Ports into the German power."

\section{Die Britse oorlogsverklaring. Invloed op die Britse wêreldryk}

Wm. Roger Louis, die skrywer van Great Britain and Germany's Lost Colonies 1914-1919 (Oxford, 1967, p.36) merk o.m. in sy studie op dat, op die dag na die Britse oorlogverklaring aan Duitsland, 'n groep Britse militêre en koloniale deskundiges onder beskerming van die "Committee of Imperial Defence" besluit het om o.m. ook Afrika en die Stille Oseaan-gebied in die stryd in Europa te betrek deur militêr teen die Duitse kolonies op te tree. Die Britse Eerste Minister Herbert Henry Asquith (1908-1916) het dié gedagte goedgekeur en 'n reeks koloniale veldtogte van stapel gestuur.

Omdat die Britse vrygeweste, soos die Unie van Suid-Afrika, ten opsigte van buitelandse aangeleenthede onderhewig aan Brittanje was, het hulle outomaties in die Eerste Wêreldoorlog betrokke geraak. Die steun wat Engeland op dié wyse ontvang het, was waardevol. 
Die Eerste Minister van die Unie van Suid-Afrika, genl. Louis Botha $(1862-1919)$, het op 10.8.1914 'n Britse versoek goedgekeur om Duits Suidwes-Afrika aan te val. Die Unieparlement het dié optrede in 'n spesiale sitting $(9-14.9 .1914)$ bekragtig. Die veldtog wat hieruit voortgevloei het, is onder die titel Die veldtog in Duits Suidwes-Afrika 1914-1915 (Pretoria, 1939; ook in Engels), deur brigade-genl. J.J. Collyer, die destydse hoof van die Generale Staf van die Unie-Verdedigingsmag, beskryf.

In sy inleiding verklaar die skrywer o.m. dat dié veldtog die enigste van sy soort was

"wat deur die stryamagte van 'n vrygewes van die Britse ryk gedurende die Groot Oorlog geheel vir eie rekening geneem, uitgewerk en deurgevoer is."

Op dieselfde wyse is deur brigade-genl. J.J. Collyer, onder die titel Die Suid-Afrikaners mel Generaal Smuts in Duits Oos-Afrika 1916 (Pretoria, 1939; ook in Engels), 'n deel van die Geallieerde krygsverrigtings in Duits Oos-Afrika uitge. werk en gepubliseer.

Die belangstellende leser word, wat die SuidAfrikaanse aandeel in die Britse koloniale oorlogvoering in Afrika betref, na die genoemde studies verwys. Dit geld ook, in 'n mindere mate, vir maj. J.G.W. Leipoldt se amptelike publikasie The Union of South Africa and the Great War 1914-1918 (Pretoria, 1924). Die inhoud van hierdie werk handel oor die veldtogte in Duits Suidwes-Afrika, Duits Oos-Afrika, Egipte en aan die westelike front in Europa.

In die volgende dele van hierdie bydrae beperk die skrywer hom tot die hoofsake van die landoorlog aan die westelike front, waar Suid-Afrikaners geveg het. Die ander fronte word slegs genoem. Dit geld ook t.o.v. die lugoorlog en die stryd ter see. Dié verhaal begin ongeveer waar die Britse staatsman sir Edward Grey (18621933) tydens die skemering van die naderende aand, terwyl die straatlampe by Whitehall aangesteek is, teenoor ' $n$ vriend opgemerk het:

"The lamps are going out all over Europe; we shall not see them lit again in our lifetime."

\section{Die stryd aan die westelike front (1914)}

Soos reeds vermeld is, het Engeland sy belofte in verband met die beskerming van die Belgiese neutraliteit nagekom en op 6.8.1914 oorlog aan Duitsland verklaar.

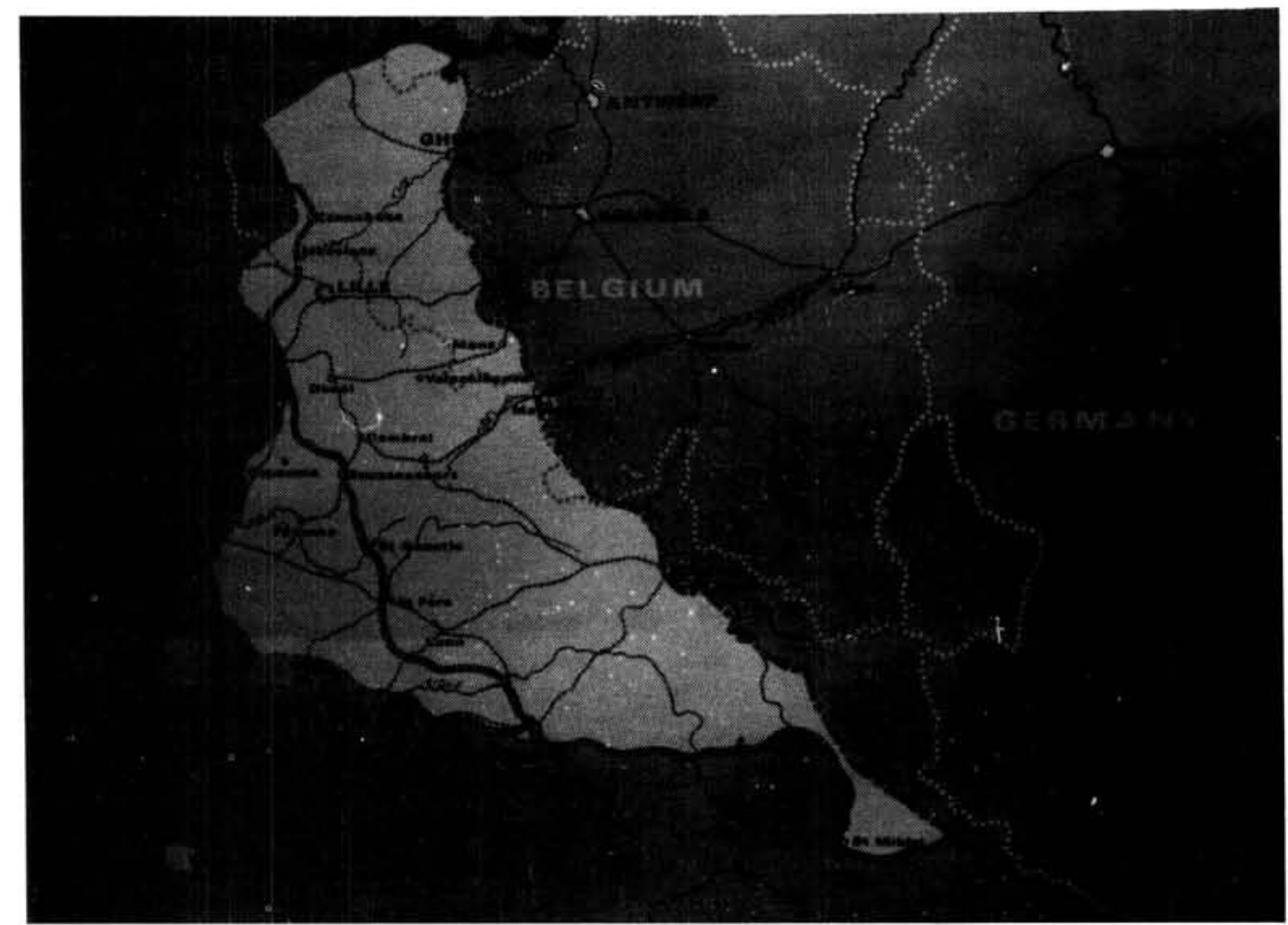

(Foto: Suid-Afrikaanse Museum van Militêre

Geskiedenis) 
Die eerste slag by leper ontbrand op 21.10.1914 met hewige gevegte by Langemark en die Duitse besetting van Diksmuide (26.10.1914), gevolg deur die stabilisasie van die IJzerfront op 22.11.1914

Die gedagte om, van Duitse kant, 'n militêre aanslag teen België te loods, was 'n deel van dié Duitse militêre beplanning waarmee graaf Alfred von Schlieffen (1833-1913), die destydse hoof van die Duitse Generale Staf van 1891-1906, hom besig gehou het indien die Duitse keiserryk in geval van 'n oorlog aan twee fronte, deur Rusland en Frankryk, aangeval sou word. Ofskoon die Schlieffen-plan later deur die opvolger van die ontwerper, genl. Helmuth von Moltke (1848-1916), in verskillende opsigte gewysig is, het die gedagte bly voortbestaan om - in so 'n geval - eers België binne te val. Frankryk kon dan eers verslaan word en daarna kon die hele beskikbare Duitse troepemag teen Rusland aangewend word. Deur dié besluit is die moontlikheid aanvaar dat, soos dit gebeur het, Engeland die Belge sou te hulp snel. In 1905 het Von Schlieffen gereken dat Duitse troepe 22 dae na die oorskryding van die Belgiese grens by die Belgies-Franse grens sou slaan. Die Duitse linie sou dan van leper oor Bergen (Mons), na Sedan en Metz loop. Na 'n maand na die invalsdag sou die Duitse front tot die linie tussen Amiens en Metz uitstrek.

Terwyl die Duitse opmars deur België aan die gang was, het 'n Britse ekspedisiemag van 100000 man onder die latere veldmaarskalk sir John French (1852-1925), die Kanaal na Frankryk oorgesteek om te probeer om die Duitsers te stuit. Die Britte het, ondanks die Duitse oormag, vertragende gevegte by Bergen (Mons) en Le Cateau uitgevoer om daarna dieper in Frankryk terug te val. Saam met Franse troepe onder genl. Josef Joffre (1852-1931) is die terugtog tot die begin van September 1914 voortgesit. Intussen het die oprukkende Duitse troepe verwag om die Franse hoofstad, Parys, binnekort te beset.

Op die walle van die Marne het die Frans-Britse terugtog tot stilstand gekom. Genl. Joffre het op 5.9.1914 ' $n$ teenaanval geloods en die Duitsers het teruggeval. Parys was gered.

Onder genl. Von Moltke se opvolger, genl. Erich von Falkenhayn (1861-1922), het die gevegte na die omgewing van die Kanaalhawens (N.W. Frankryk) verplaas. Daar het verbete Franse en Britse weerstand 'n Duitse deurbraak verydel.
Op 7.10.1914 is die strategies belangrike stad leper, agter die Kanaalhawens, in die uiterste weste van België, deur die Duitsers beset. 'n Week later herower die Britte dié stad en op 16.10.1914 het die Belgiese leër onder koning Albert (1875-1934) agter die IJzerlinie terug geval om daar, tot die einde van die oorlog. stand te hou.

Na die eerste slag aan die Marne (5.9.19149.9.1914) het die oorlogvoerendes mekaar deur omvattende bewegings probeer uitwis. Dié pogings het misluk en aan die begin van November 1914 was die hele westelike front, van die Kanaalkus tot die Frans-Switserse grens, 'n aaneengeslote, beweginglose linie. Die bewegingsoorlog was verlam en het in 'n stelling- of loopgraafoorlog oorgegaan. Daar was loopgrawe van die IJzerfront in die weste, oor Arras (Atrecht) en Amiens, ten suide van Reims, oor Toul en Epinal tot Belfort.

Herhaalde kere is van Duitse en Geallieerde kant hardnekkige pogings aangewend om die front te deurbreek. Slagtings in Artois en Champagne, by Verdun in die ooste en die Somme in die weste en in Vlaandere het eers in die tweede helfte van 1918, voorafgaande aan die Duitse militêre ineenstorting, tot tasbare resultate gelei. Miljoene menselewens en ontsaglike hoeveelhede oorlogstuig het in dié jare aan die westelike front verlore gegaan.

Die hoop is gekoester dat die dooiepunt aan die genoemde front, in die ooste of elders, verbreek kon word.

Aan die begin van die oorlog het Russiese magte vaste voet in Oos-Pruise verkry. Op 30.8.1914 het veldmaarskalk Paul von Beneckendorf und Von Hindenburg (1847-1934) en genl. Erich Ludendorff (1965-1937) die Russe in die slag van Tannenberg verslaan. In 1915 sou ' $n$ herhaling van hierdie wapenfeit naby die Masoeriese mere, ook in Oos-Pruise, plaasvind. By Tannenberg het die Russe 300000 man verloor. Daarna het die leiers van Rusland, Duitsland en sy bondgenoot Oostenryk-Hongarye, mekaar met wisselende sukses in Pole beveg. Tot 1917 sou dié oorlog aan twee fronte gevoer word.

\section{Die stryd aan die westelike front (1915)}

In 1915 het die oorlog aan die westelike front o.m. tot die tweede slag van leper (April-Mei 
1915) en die eerste Duitse gasaanval tussen Steenstrate en Pilkem gelei. Franse en Britte het o.m. groot aanvalle in Champagne van stapel gestuur. Duisende het gesneuwel, sonder dat groot terreinwinste behaal is. Die hoogtepunt in dié stryd was die worsteling om die besit van Verdun (Februarie-Desember 1915), waar meer as 700000 Franse verdedigers en Duitse aanvallers om die lewe gekom het.

Aan die oostelike front het die Duitse generaal Von Mackensen in Mei 1915 die Russe na die slag van Gorlice uit Galisië verdryf. Daardeur het die Russiese deel van Pole onder Duitse beheer gekom. Die Russe het met gebrek aan voorrade te kampe gekry en om dit te probeer verhelp het die Geallieerdes ' $n$ aanval op die Dardanelle beplan om, oor die Swartsee, voorrade na Odessa (Suid-Rusland) te kan stuur. $\mathrm{Na}$ die landing by Gallipoli $(25.4 .1915)$ het ' $n$ veldtog gevolg waarin die Turkse verdedigers staande gebly het. Die Engelse, Franse, Nieu-Seelanders en Australiërs (ANZAC) het groot verliese gely en hulle het slegs daarin geslaag om die hawestad Saloniki as 'n moontlike basis te behou. Die aantal gesneuwelde soldate van Engeland en die Britse vrygeweste was 34000 , die Franse ongevalle ongeveer 10000 en die skrywer Robert Rhodes James het in sy studie Gallipoli (London, 1975) treffend verklaar:

"There is no profit and loss account for Gallipoli" (p. 355).

En wie dink vandag nog aan slagveldbenamings soos "Plugge's Plateau", "Shrapnel Valley", "Lone Pine" en "Bloody Angle"?

Die Oostenrykse druk op die Russe is inmiddels verlig, deurdat Italië, ten spyte van sy verbond met Duitsland en Oostenryk, in Mei 1915 aan die kant van die Geallieerdes tot die oorlog toegetree het. Dié optrede het Oostenryk ook verhinder om bystand aan die Duitsers aan die westelike front te verleen.

Ten spyte van die Geallieerde maatreëls het Rusland sienderoë swakker en swakker geword. In Oktober 1915 het genl. Brusilow, in 'n laaste kraginspanning, deur die Oostenrykse linies gebreek en duisende krygsgevangenes gemaak. In Maart 1917 is die tsaar gedwing om af te tree, die Kommunistiese revolusie het die einde van die ou bedeling beteken en in Maart 1918 het die nuwe Rusland die vrede van Brest-Litowsk met die oorwinnaars, Duitsland en Oostenryk, gesluit.

\section{Die stryd aan die westelike front (1916)}

In 1916 was Rusland feitlik uitgeskakel. Duitsland het nou probeer om aan die westelike front tot ' $n$ beslissing in sy guns te kom. Veral op aandrang van kroonprins Wilhelm is pogings aangewend om Verdun te verower en om daar die Franse leërs uit te dun. Dié worsteling het op 21 Februarie 1915 met 'n Duitse aanslag begin. Die Franse het die aanslag deurstaan en in Engeland het veldmaarskalk Herbert Kitchener (1850-1916) nuwe leërs gevorm wat, aan die Somme, geen terrein van betekenis kon verower nie. Die Somme-offensief begin op 24.6.1916 met ' $n$ kanonnade van ongeveer 3000 vuurmonde van $75-370 \mathrm{~mm}$ en spesiale loopgraafartillerie. Die Duitsers staan teenoor hierdie Frans-Britse mag met minder as 1000 kanonne en ' $n$ geringer aantal vliegtuie. Hulle. is verplig om die stryd by Verdun te staak om versterkings na die Somme te kan stuur. Intussen verloor die Geallieerde divisies duisende lede en het hulle minder as $10 \mathrm{~km}$. terrein verower. Die offensief duur tot November 1916. Vir die Geallieerdes was dit ' $n$ groot teleurstelling. Enorme verliese is aan albei kante gely en tydens die stryd is die Duitse opperbevel aan die westelike front gewysig. Veldmaarskalk Von Hindenburg en genl. Ludendorff het die leiding oorgeneem.

\section{Die Suid-Afrikaners aan die westelike front (1916)}

$\mathrm{Na}$ die beëindiging van die veldtog in Duits Suidwes-Afrika by Khorab op 9.7.1915 het die Unieregering ' $n$ infanteriebrigade, bekend as 1 Suid-Afrikaanse Infanteriebrigade (1SAl), bestaande uit vrywilligers, op die been gebring. Hierdie soldate sou die Unie van Suid-Afrika aan die westelike front verteenwoordig. Die brigade het uit vier regimente bestaan en is deur brig. genl. H.T. ("Tim") Lukin (1860-1925) aangevoer. Die sterkte was 160 offisiere en 5648 ander range. Hierdie troepe het in November 1918 in Engeland aangekom en het met frontopleiding begin. Dié werksaamhede is onderbreek deur 'n ekspedisie na Egipte om die Senoessies op die wesgrens te verslaan (Februarie 1916). Op 20.4.1916 was die brigade in Marseilles terug om vandaar, met uitsondering van lede wat tydelik in kwarantyn geplaas is, voorlopig na die landstreek agter die westelike deel van die front te gaan. Die SAl is aan 9 Skotse Hooglander divisie, onder genl.-maj. Furse, toegevoeg. Die tydelike hoofkwartier was Bailleul. Op 29.4.1916 het ' $n$ inspeksie deur veldmaarskalk sir Douglas Haig (1861-1928) gevolg en op 
14.6.1916 het hierdie divisie opdrag ontvang om na die Sommefront op te ruk.

Op 2.7.1916 het 'n deel van die SAI, naby Montauban, sy plek in die frontlinie ingeneem, terwyl die orige lede as reserwes aangewend is.

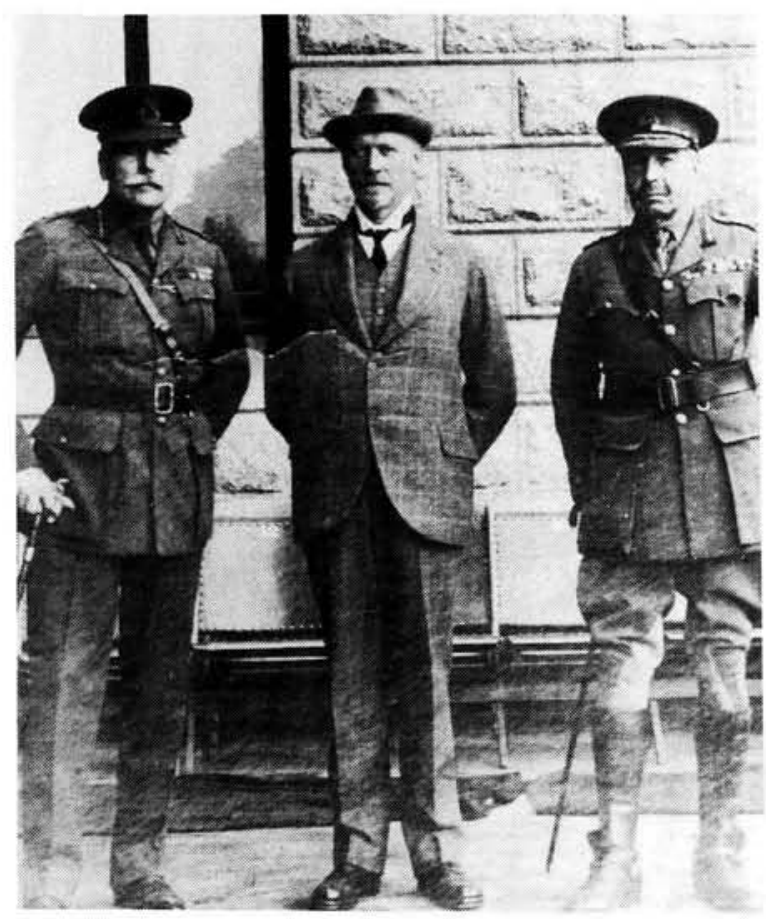

Van I na r:

Sir Douglas Haig, Genl. J.C. Smuts en Genl. H.T. (Tim) Lukin.

(Foto: Suid-Afrikaanse Museum van Militêre Geskiedenis)

$\mathrm{Na}$ optrede teen die vyand en teenaanvalle is op 14.7.1916 'n Geallieerde aanval aan die front tussen Pozières en Longueval, met insluiting van die sektor van Delvillebos, teen die vyand geloods. In Delvillebos was 1SAl in dié stryd betrokke wat vyf dae geduur het. Hewige bombardemente van die kant van die Duitsers het die Suid-Afrikaners groot verliese besorg. Op 20.7.1916 is die brigade deur 'n Britse brigade afgelos. Op die genoemde dag het kol. Thackeray, drie offisiere en 140 manskappe ongedeerd uit die verwoeste bos te voorskyn getree. Voor die slag was die sterkte van die brigade 3153. Tussen 1.7.1916 en 20.7.1916 is 2815 ongevalle gely, nl. 502 gesneuweldes, 1735 gewondes en 578 vermistes. Na die geveg was daar nog 833 man oor wat slaggereed was.

$\mathrm{Na}$ aanleiding van hierdie geveg het die Britse deskundige kapt. B.H. Liddell Hart in sy werk History of the First World War (London, 1972, p. 247) verklaar:
"... in the depths of Delville Wood, .... the South African's made their supreme sacrifice of the war - where today a white stone colonnade of peaceful beauty commemorates, and contrasts with, the bloodiest battle-hell of 1916."

Dit was in die loop van hierdie bloedige slag dat weerman W.F. Faulds op 18.7.1916 die eerste Victoriakruis (VC) van die brigadelede verkry het.

$\mathrm{Na}$ die oorlog het 'n komitee onder sir Percy Fitzpatrick (1862-1931) en sir Abe Bailey (1864-1940) gelde in Suid-Afrika begin insamel om ' $n$ treffende gedenkteken op die slagveld op te rig. Dié monument is op 10.10.1926 deur sir Percy aan die destydse premier van die Unie van Suid-Afrika, genl. J.B.M. Hertzog (1866-1942), oorgedra.

Tydens die oorblywende maande van 1916 het die brigade aan die slag van die Somme bly deelneem. Op 5.8.1916 was die sterkte van 1SAI 62 offisiere en 2523 manskappe. Tien dae later, van 9-19 Oktober 1916, het die ongevalle wat by die Warlencourtkoppie gely is, tot ongeveer 1150 gestyg. Op 21.10.1916 is die Suid-Afrikaanse gedeelte na die Maretzbos teruggetrek om daarna na Arras (Atrecht) oorgeplaas te word.

Op 2.12.1916 is genl. Lukin, met die rang van genl.-maj., tot bevelvoerder van 9 Divisie bevorder. Hy is, as bevelhebber van die brigade, deur It.-kol. Dawson opgevolg.

\section{Die stryd aan die westelike front (1917)}

$\mathrm{Na}$ aanleiding van die afkondiging van die onbeperkte duikbootoorlog (1.2.1917) deur Duitsland het die Verenigde State van Amerika op 6.4.1917 besluit om, aan die kant van die Geallieerdes, tot die oorlog toe te tree. Hierdie besluit was van onskatbare waarde vir die bondgenote. Nie alleen was die posisie aan die westelike front moeilik vir die Geallieerdes, maar - soos reeds vermeld is - het die tsaristiese Rusland inmekaar gestort. Die tsaar is op 15.3.1917 afgesit, die sosialis Alexander Kerenski het die bewind oorgeneem, terwyl die Duitse regering die Russiese revolusionêre leier Wladimir Uljanow (Lenin) (1870-1924) in die geleentheid gestel het om uit Switserland na Rusland terug te keer. Ook het Leon Trotski (1879-1940) uit die vreem- 


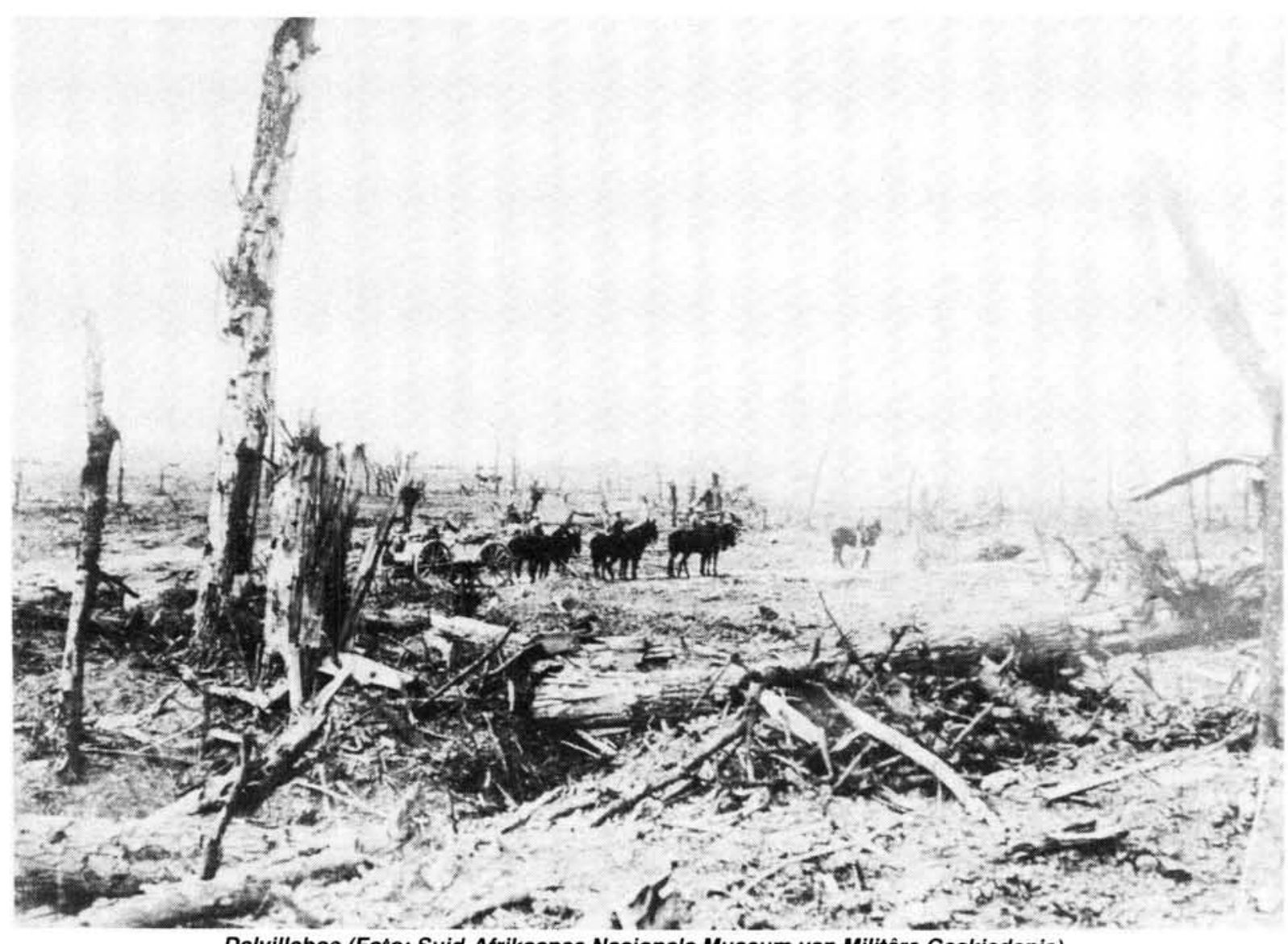

Delvillebos (Foto: Suid-Afrikaanse Nasionale Museum van Militêre Geskiedenis)

de in Rusland verskyn. Die tweede (Bolsjewistiese) revolusie is georganiseer, Lenin het die mag oorgeneem (7.10.1917) en in Maart 1918 (3.3.1918) is die vrede van Brest-Litowsk tussen Rusland, Duitsland en Oostenryk-Hongarye gesluit. Rusland was uit die oorlog en die Duitsers kon meer aandag aan die westelike front wy.

Die jaar 1917 was moeilik vir die Geallieerdes. Die Britte het ' $n$ offensief by Arras (Atrecht) begin loods waar o.m. die derde leër onder genl. sir Edmund Allenby in April 1917 'n oorwinning by Vimy behaal het. Die Duitsers het die Geallieerdes aan die Aisne afgeweer en in dieselfde maand het die Franse offensief by Chemin des Dames misluk. In Mei en Junie het muitery onder die Franse troepe uitgebreek, terwyl veldmaarskalk Haig die Franse probeer help het deur in Junie 1917 ' $n$ offensief by leper (derde slag van leper) in die omgewing van Wijtschate van stapel te stuur. In Augustus volg die verowering van Langemark (15.8.1917) deur die Britte, gevolg deur die inname van Zonnebeke. Poelkapelle (20.9.1917) en Passendale (20.10.1917).

Die jaar 1917 eindig met die verowering van Jerusalem op die Turke deur ' $n$ Britse mag onder genl. sir Edmund Allenby. Dié troepe het van Egipte gekom en die hele Palestina in 1918 verower.

\section{Die Suid-Afrikaners aan die westelike front (1917)}

In 1917 was 1SAl betrokke by die slag om Arras (Atrecht). 'n Deel van dié front, tussen St Pancras tot die Scarpe was deur die brigade beset. Daar is - soos elders - voorbereidings vir veldmaarskalk Haig se offensief getref. Genl. J.C. Smuts (1870-1950) het die brigade op 6.4.1917 geïnspekteer. Aanvalle het, tussen 12-15 April 1917, 720 ongevalle veroorsaak. Daarna is die brigade tydelik aan die front onttrek en met 1448 vrywilligers aangevul.

Op 31.7.1917 het die derde slag om leper begin. Die brigade het vanaf 17.9.1917 daaraan deelgeneem, is op 22.9.1917 van die front verwyder en het heelwat ongevalle gely. Op 12 tot 13 Oktober 1917 is die Suid-Afrikaners weer terug aan die front waar, op 6.11.1917, die offensief ten einde geloop het. Die verliese is vervol- 


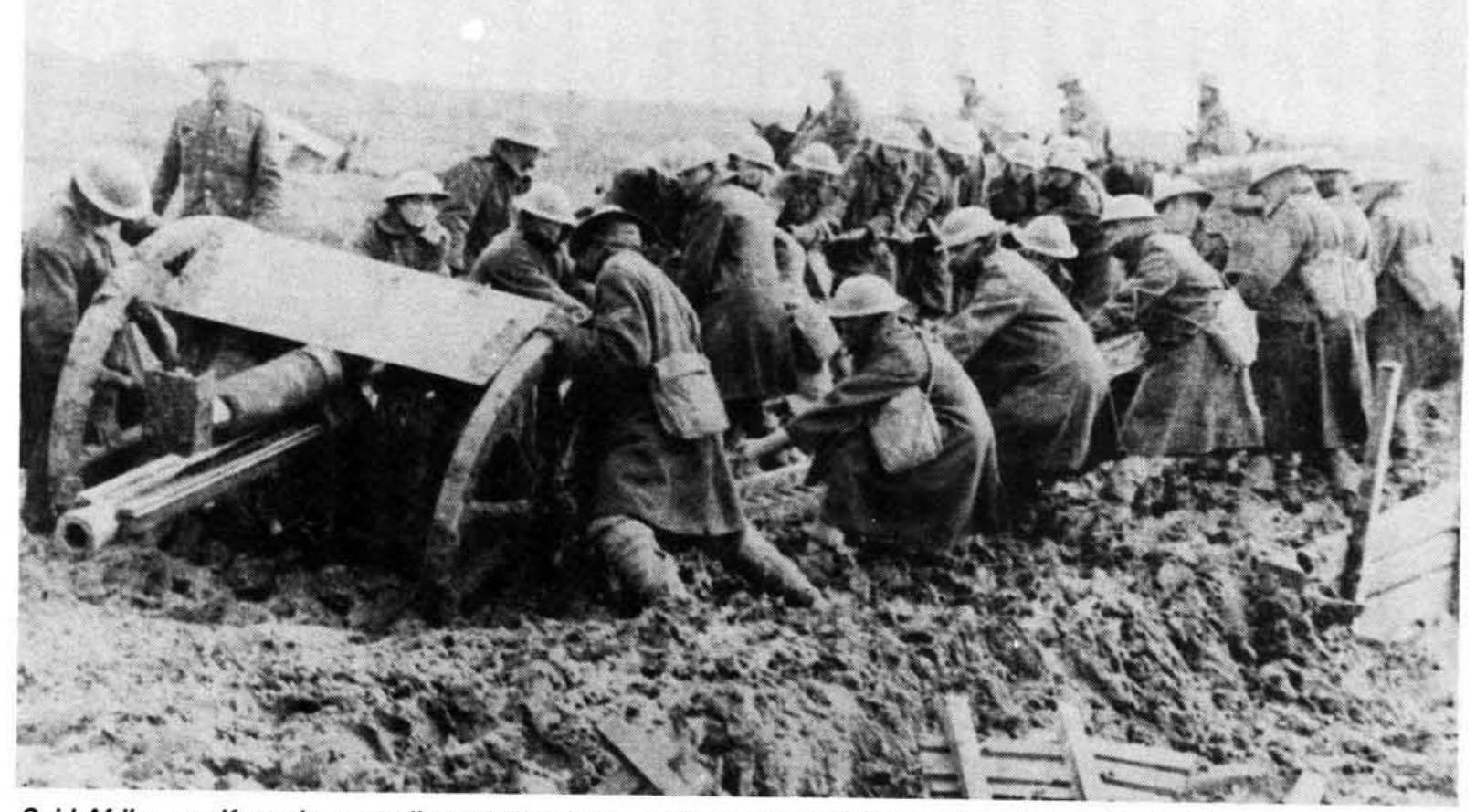

Suid-Afrikaanse Kanoniers aan die westelike front worstel om 'n artilleriestuk deur die modder te sleep. (Foto 851001084 SAW Argief)

gens aangevul en op 4.12.1917 is die brigade, naby Quentin Ridge, terug aan die front waar patrolliewerk deur slegte weersomstandighede belemmer is. Op 4.12.1917 was die brigade se sterkte 148 offisiere en 3621 manskappe en op 23 Januarie 1918, na groot verliese, nog 79 offisiere en 1661 manskappe. Op 31.1.1918 is die Suid-Afrikaanse vrywilligers uit die loopgrawe om ' $n$ maand te rus. Op 17.2.1918 is 'n gedenkdiens by Delvillebos gehou.

Op 21.3.1918 het die laaste Duitse offensief van die oorlog, voorafgegaan deur kanonvuur van duisende vuurmonde, losgebars.

\section{Die stryd aan die westelike front (1918)}

Genl. Ludendorff het vroeg voorbereidings vir ' $n$ grootse Duitse offensief getref en 35 divisies in gereedheid gehou. Op 21.3.1918 het die poging begin om die Britse en Franse leërs van mekaar te skei en' daarna afsonderlik te vernietig. Die aanvallers het daarin geslaag om, naby St. Quentin, 'n bres van $15 \mathrm{~km}$ breedte in die Geallieerde linies te slaan en tot naby Amiens op te ruk. In April val hulle die Britte wes van Lille (Rijssel) aan en in Mei volg ' $n$ aanslag teen die Franse aan die Aisne. Die opmars rol voort tot die Marne en die Duitsers staan op ongeveer 65 $\mathrm{km}$ afstand van Parys.

As 'n reaksie op hierdie grootskaalse aanslag besluit die Geallieerdes op 10.4.1918 om die Britse en Franse troepe onder die eenhoofdige leiding van maarskalk Ferdinand Foch (1851-1929) te plaas. Onder sy leiding en met onder hom maarskalk Henri Philippe Petain (1856-1951) (Franse troepe), sir Douglas Haig (Britse troepe) en genl. John J. Pershing (1860-1948) (Amerikaanse troepe) sou die oorlog verder gevoer word. Die Belgiese leër sou, onafhanklik, onder leiding van koning Albert (1875-1934) bly.

Die tweede slag om die Marne het ' $n$ wending geneem nadat die Duitsers in Julie 1918 tevergeefs probeer het om die rivier oor te steek. $\mathrm{Na}$ twee weke is hulle tot oor die Aisne teruggedryf. Die gevaar vir Parys en die Kanaalhawens was, ook danksy die steeds kragtiger wordende Amerikaanse steun, verby. Die Duitsers het begin 
uitgeput raak, terwyl hulle bondgenote verslaan is of ineengestort het. Op 30.9.1918 het Bulgarye onvoorwaardelik oorgegee. In Oktober 1918 het Turkye oorgegee en het die OostenryksHongaarse monargie opgebreek. Reeds vroeër, op 8.8.1918, het die uiteindelike Geallieerde offensief aan die westelike front begin. Troepe, 800 tenks en lugondersteuning het die Duitsers by Amiens laat terugval. Die Amerikaners het suksesse by Verdun behaal, terwyl die Belge by leper aangeval het. Teen die einde van September het Hindenburg en Ludendorff besef dat die stryd verlore was. Hindenburg het op vredesonderhandelinge begin aandring en op 3.10.1918 is met president Woodrow Wilson (1856-1924) in verbinding getree om oor ' $n$ wapenstilstand te onderhandel. Reeds in Januarie 1918 het die Amerikaanse staatshoof sy veertien punte in verband met ' $n$ moontlike vrede voorgestel. Voordat die beoogde wapenstilstand op 11.11.1918 'n voldonge feit sou word, het o.m. die volgende gebeurtenisse in en met betrekking tot Duitsland plaasgevind. Op 28.10.18 het muitery op die Duitse vloot (Kiel) plaasgevind, op 29.10.1918 het keiser Wilhelm II uit Berlyn vertrek en hom na die Duitse militêre hoofkwartier in Spa (België) begewe. Hy het gehoop dat die Duitse leër hom en sy troon sou beskerm. Die gedagte is nie verwesenlik nie en in die nag van 9.10.1918 het die keiser, na sy aftrede, die wyk na Nederland geneem. Die Nederlandse regering het die oudkeiser vestigingsverlof toegestaan op voorwaarde dat hy hom nie met politieke bedrywighede sou bemoei nie. Op 15.5.1920 het, na 'n tydelike verblyf in Amerongen (Nederland), die vestiging van die oud-keiser en sy gade, oudkeiserin Auguste Victoria, in die kasteel Doorn, naby Utrecht, gevolg. Die oud-keiserin is in 1921 oorlede en die oud-keiser het in 1922 weer met prinses Hermine von Reusz in die huwelik getree. Die prinses is in 1947 oorlede en die oudkeiser het op 4.6.1941 in sy kasteel gesterf. Behalwe die oud-keiser en sy gemalin het die Duitse oud-kroonprins, Wilhelm, op 12.11.1918 die Nederlandse grens oorgesteek. Hy is van 1918-1924 op die destydse eiland Wieringen geïnterneer en het in 1924 na Duitsland teruggekeer.

$\mathrm{Na}$ die aftrede van keiser Wilhelm $\|$ het die sosialis Friedrich Ebert (1871-1925) hoof van die nuwe Duitse regering geword. Die Duitse parlement moes oor die wapenstilstand en die ; vrede besluit. Tot Februarie 1919 was Ebert kanselier. Hy is in die genoemde maand deur die konstitusionele vergadering in Weimar as president van die jong Duitse republiek aangewys.
Só het die Eerste Wêreldoorlog ten einde geloop. Volgens sommige skattings het 65 miljoen gewapendes in hierdie konflik van wêreldomvang teenoor mekaar gestaan. Van hulle is $8 \frac{1}{2}$ miljoen gesneuwel, ' $n$ verdere 29 miljoen is gewond, gevang of vermis. Daar was 10 miljoen oorlogweduwees en wese. Die materiële skade het biljoene bedra.

\section{Die Suid-Afrikaners aan die westelike front (1918)}

In Maart 1918 het 1 SAl in die omgewing van Haudicourt teruggeval en in die eerste twee dae 900 man verloor. Ook is groot verliese by Marrières (24.3.1918) gely. Daarna het, van 27.3.1918-5.5.1918, die slag om die Lys gevolg. Gevegte by Messines (begin April 1918) en die dorp Kemmel (12.4.1918) het daartoe gelei dat die oorblyfsels van die vroeëre brigade in ' $n$ enkele regiment gegroepeer is. Die ou, tradisionele benaming van die eenheid van 59 offisiere en 1527 manskappe is behou, maar o.m. is ' $n$ tweetal Skotse regimente in die nuwe 1SAI-brigade opgeneem. Op 29.4.1918 het die laaste geveg aan die Lysfront plaasgevind en op 5.5.1918 is die genoemde troepe uit die frontlinie. Hulle is terug op 19.7.1918 en het Meteren verower. Op 17.10.1918 is, noord van Le Cateau, die Selle (suid van Valenciennes) oorgesteek. Inmiddels was die Duitse terugtog na die Hindenburglinie, by Doornik (Douai), Kamerijk, St. Quentin en Laon, in volle gang. Op Wapenstilstanddag was 1SAI in die mees oostelike posisie van die Britse troepe aan die westelike front gestasioneer. Op dié tydstip was die brigade 'n onderdeel van 66 Divisie. Op dieselfde dag was die Duitse weerstandlinie wes van Antwerpen, wes van Brussel, wes van Dinant, by Sedan en Verdun, wes van Metz en oos van Belfort, gevestig.

Die totale ongevalle van die Suid-Afrikaanse troepe in Frankryk was ruim 12000 . Hulle rus o.m. in militêre begraafplase in Delvillebos, Warlencourt, Roeux, Messines, Passendale, naby Poperinghe en elders en aan hulle herinner oorlogsmonumente in ons land. Blankes, Kleurlinge en Swartes, het o.m. aan die westelike front, die hoogste offer gebring...

\section{Die vredesverdrae (1919-1923)}

Op 11.11.1918 is die wapens aan die westelike front en elders neergelê. In 1918: The last act (London, 1958, p. 247) het die skrywer Barry Pitt 
dié oomblik (om elfuur) in die volgende woorde probeer skets:

"By midday, silence lay across the battlefields like a blessing. Men climbed out of their riflepits or shallow ditches - for the elaborate trench systems were miles away to the westward - stood erect in open country with feelings of apprehension and uncomfortable nakedness, and then, as the wonder and release from danger took hold of their minds, they became exited."

Só het, na ruim vier jaar van stryd, die wapenstilstand gekom. Vyf jaar na die gebeure by Serajewo, op 28.6.191, is - in Versailles - die vrede tussen die Geallieerdes en Duitsland onderteken. In dieselfde jaar het die vredesverdrae met Oostenryk (St. Germain) en Bulgarye (Neuilly) gevolg. In 1920 is vrede gesluit met Turkye (Sèvres), gevolg deur die ondertekening van 'n nuwe verdrag in Lausanne (1923). Hongarye het in 1920 die vrede van Trianon gesluit.

Die militêre voorwaardes van Versailles het o.m. behels dat Duitsland ontwapen is, maar 'n leër van 100000 man mag besit (dienstydperk 12 jaar). Die nuwe Duitse weermag mag oor ligte bewapening beskik, maar nie oor tenks, vliegtuie, gas of swaar kanonne nie. Die Duitse oorlogsvloot moet aan die Geallieerdes oorgedra word. Die Rynland word voorlopig deur die Geallieerdes beset en ' $\mathrm{n}$ strook van $50 \mathrm{~km}$ ten ooste daarvan moet heeltemal gedemilitariseer word.

Die gebiedsvoorwaardes het o.m. die teruggawe van Elsas-Lotaringe aan Frankryk behels. Eupen en Malmédy moet aan België oorgedra word en Denemarke ontvang Noord-Sleeswyk na ' $n$ volkstemming. Die nuwe Poolse staat verkry dele van Silesië, Pose en Wes-Pruise. Dantzig word ' $n$ onafhanklike stadstaat en die Duitse kolonies word aan die oorwinnaars afgestaan.

Kragtens die ekonomiese bepalings is Duitsland verplig om 137 miljoen goudmark aan skadevergoeding te betaal.
Namens die Unie van Suid-Afrika het genls. Louis Botha en J.C. Smuts die vredesverdrag van Versailles onderteken. Op die dag van die ondertekening het Eerste Minister genl. Louis Botha op sy agendapapier geskryf:

"28 Juni 1919 Gods rechten zal op alle volkeren rechtvaardig toegepast worden onder de nieuwe Zon, en wij zullen volharden in het gebed, dat dit op den mensdom in liefde, Vrede en Christelikheid worden toegepast vandaag gedenk ik 31 Mei 1902." - F.V. Engelenburg: Genl. Louis Botha (Pretoria 1928, pp. 339,351$)$.

Van genl. J.C. Smuts is o.m. die volgende gedagte afkomstig:

"I have signed the Peace Treaty, not because I consider it a satisfactory document, but because it is imperatively necessary to close the war; because the world needs peace above all, and nothing could be more fatal than the continuance of the state of suspence between war and peace. The six months since the armistice was signed have perhaps been as upsetting, and ruinous to Europe as the previous four years of war. I look upon the Peace Treaty as the close of those two chapters of war and armistice, and only on that ground do I agree to it." - J.C. Smuts: Jan Christian Smuts (London, 1952, p. 234).

\section{Geraadpleegde en aanbevole leesstof}

Behalwe die werke wat in die teks genoem is, word die aandag gevestig op 'n uitstekende bibliografie in kapt. B.H. Liddell Hart se genoemde History of the First World War (London, 1972), p. 466-490. Verder word 0.m. aanbeveel: H. Brugmans: Geschiedenis van den Wereldoorlog (Amsterdam, 1936); Walter Görlitz: Der Kaiser... (Göttingen, 1965); R. Parkinson: The Origins of World War One (London, 1970); J. Wheeler-Bennett: Hindenburg The Wooden Titan (New York, 1967); V. Valentin: Knaurs Deutsche Geschichte (München, Zürich, 1960); en S. von Ilsemann: Der Kaiser in Holland (München, 1967), deel 1.

* Kol. (dr.) Jan Ploeger, SSO Argief en Navorsing, SAW, 1964-1973. Staatshistorikus, RSA, 1973-1983. 